УДК 616.132-007.64:616.132.2]-089

\title{
Хірургічне лікування аневризм аорти в поєднанні з ураженням вінцевих артерій серця
}

\author{
Жеков І. І., Кравченко В. І., Кравченко І. М., Зінченко Г. А., Перепелюк А. І., \\ Вайда В. В.
}

ДУ «Національний інститут серцево-судинної хірургії імені М. М. Амосова НАМН» (Київ)

\begin{abstract}
Останнім часом зросла частка операцій у пацієнтів із поєднаною патологією - наявністю аневризм аорти та ураження вінцевих артерій. Поєднані оперативні втручання при аневризмах аорти із супутнім ураженням вінцевих артеріях наразі набули значного поширення. Частка таких втручань у сучасних кардіохірургічних центрах становить 15-30\%. Для зменшення операційного ризику і вірогідності летального результату при виконанні подібних операцій необхідне скорочення тривалості штучного кровообігу та ішемічного часу для міокарда, що є основною проблемою.
\end{abstract}

Мета роботи - оцінити ефективність хірургічної корекції аневризм аорти в поєднанні з реваскуляризацією міокарда.

Матеріали та методи. У період з 01.01.2010 по 31.12.2017 було прооперовано 105 пацієнтів із приводу аневризм аорти та супутнього ураження вінцевих артерій.

Висновки. Для покращення безпосередніх результатів операції у пацієнтів з аневризмами аорти і супутнім ураженням вінцевих судин при наявності субоклюзій основних гілок вінцевих артерій першим етапом операції повинна виконуватися повна реваскуляризація міокарда, у подальшому -корекція патології аорти.

Ключові слова: аневризма аорти, вінцеві артерії, коронарне шунтування.

Поєднані оперативні втручання з приводу аневризм аорти із супутнім ураженням вінцевих артеріях за останні десятиріччя набули значного поширення. Частка таких втручань у сучасних кардіохірургічних центрах становить 15-30\% [3-5]. Для зменшення операційного ризику і вірогідності летального результату при виконанні подібних операцій необхідне скорочення тривалості штучного кровообігу та ішемічного часу для міокарда, шо $є$ основною проблемою $[1,2,5]$.

Мета роботи - оцінити ефективність хірургічної корекції аневризм аорти в поєднанні з реваскуляризацією міокарда.

Матеріали та методи. За період з 01.01.2010 по 01.01.2017 в ДУ «НІССХ імені М. М. Амосова НАМН» на хірургічному лікуванні з приводу аневризми аорти знаходилися 404 пацієнти, з них було прооперовано 105 пацієнтів з поєднаною патологією аорти та вінцевих артерій. У відділенні хірургічного лікування патології аорти першим етапом коригували патологію вінцевих артерій серця, другим етапом - аневризму аорти та патологію аортального клапана.

Переважну більшість хворих становили чоловіки $68(64,8 \%)$. Вік хворих коливався від 38 до 77 років, у середньому становив $61,2 \pm 8,6 \mathrm{p}$.

У всіх пацієнтів виконано клінічні та інструментальні дослідження, що включали ЕКГ, рентгеногра- фію органів грудної порожнини, ЕхоКГ, коронаровентрикулографію. Проведено хронометрію загальної тривалості втручання, часу штучного кровообігу, часу перетиснення аорти.

Односудинне ураження вінцевих артерій спостерігали у 31 (29,5\%) пацієнта, двосудинне - у 47 (44,8\%), трисудинне і більше - у $27(25,7 \%)$.

Для хірургічної корекції аневризм аорти були виконані такі оперативні втручання:

- протезування аортального клапана з екзопротезуванням висхідної аорти (операція Robicsek) - у 38 (36\%) пацієнтів;

\section{Таблиця 1}

Розподіл пацієнтів з аневризмами аорти та супутнім ураженням вінцевих артерій по роках

\begin{tabular}{lc} 
Роки & Пацієнти - $\mathbf{n}$ (let.) \\
\hline 2010 & 3 \\
\hline 2011 & 10 \\
\hline 2012 & 6 \\
\hline 2013 & $13(2)$ \\
\hline 2014 & 8 \\
\hline 2015 & $18(1)$ \\
\hline 2016 & 21 \\
\hline
\end{tabular}




\section{Таблиця 2}

Розподіл пацієнтів з аневризмами аорти та супутньою патологією вінцевих артерій залежно від типу ураження aорmu

\begin{tabular}{|c|c|c|c|c|c|c|c|c|}
\hline \multirow[b]{2}{*}{ Типи аневризм } & \multicolumn{8}{|c|}{ Роки } \\
\hline & 2010 & 2011 & 2012 & 2013 & 2014 & 2015 & 2016 & 2017 \\
\hline ГРАА & & & 1 & 2 & & 5 & 3 & 4 \\
\hline XPAA & & & & 1 & & & 4 & 2 \\
\hline Аневризми без розшарування & 3 & 9 & 6 & 10 & 8 & 13 & 14 & 20 \\
\hline
\end{tabular}

- протезування аортального клапана 3 протезуванням висхідної аорти (операція Bentall-de-Bono) - у 41 (39\%) пацієнта;

- супракоронарне протезування висхідної аорти - у 22 (21\%) пацієнтів;

- операція Wheat - у 3 (3\%) пацієнтів;

- артеріальне переключення судин дуги аорти - в 1 (1\%) пацієнта.

АКШ-1 виконане у 31 (29,5\%) хворого, АКШ-2 - у 47 (44,8\%), АКШ-3 - у 19 (18,1\%), АКШ-4 - у 7 (6,7\%), АКШ-5 - у 1 (0,9\%). Таким чином, середня кількість шунтів на одного хворого становила 1,74 шунтів. Натомість у 2007 р. середня кількість шунтів на хворого 3 аневризмою аорти та супутнім ураженням вінцевих артерій становила 1,16; у 2008 - 1,2; у $2009-1,25$; $(\mathrm{p}<0,05)$.

Хірургічна методика. Всі втручання було виконано в умовах штучного кровообігу з помірною гіпотермі$€ ю\left(30-32^{\circ} \mathrm{C}\right)$ і використанням холодової кардіоплегії розчином кустодіолу 20 мл/кг 3 комбінованим шляхом введення (анте-, ретроградним) із додаванням зовнішнього охолодження. Канюлювали висхідну аорту, за винятком випадків канюляції лівої феморальної артерії у пацієнтів із розшаровуючими аневризмами аорти; роздільно канюлювали порожнисті вени і дренували порожнину лівого шлуночка через праву верхню легеневу вену. Одночасно з початком стернотомії інший хірург виконував забір поверхневої аутовени з ноги.

Після початку штучного кровообігу перетискували аорту. Кустодіол вводили в кількості 20 мл/кг ретроградно через коронарний синус, або антеградно через корінь аорти, або після розсічення аорти у вічка вінцевих артерій, якщо розшарування на них не поширювалося. Якщо аорта була перетиснула понад 2,5 години, введення кустодіолу повторювали.

Спочатку виконували дистальні анастомози аутовен із коронарними артеріями дистальніше місця ураження. Потім знімали затискач з аорти, відновлювали серцеву діяльність. Проксимальні анастомози виконували на працюючому серці при боковому відтисненні аорти. Комбінація і послідовність етапів операції мають загальні протоколи, але можуть потребувати індивідуалізації у конкретних хворих, що визначається особливостями поєднання і вираженості клапанної та вінцевої патології.
Результати та обговорення. У відділення хірургії патології аорти госпіталізували хворих 3 аневризмами аорти. Вінцева патологія у них, як правило, не супроводжувалася достовірною клінічною симптоматикою. Тому ураження вінцевих артерій були виявлені при коронарографії як обов’язковому методі обстеження хворих на доопераційному етапі (для чоловіків старших 45 років і жінок старших 50 років) або у випадках виявлення змін на ЕКГ у молодших хворих, у пацієнтів 3 аневризмою аорти (не розшаровуючою).

3 огляду на високий ризик надриву інтими при розшаровуючих аневризмах у таких пацієнтів виконувалася комп'ютерна томографія з контрастуванням для визначення стану коронарного русла. За даними КТ цій групі пацієнтів за потреби виконувалася корекція уражень вінцевих артерій.

Госпітальна летальність у пацієнтів, яким виконували хірургічне лікування аневризм аорти та одномоментну корекцію уражень коронарних артерій, склала $3.9 \%$, що перевищує показники при ізольованому аортокоронарному шунтуванні. Причини летальності, на наш погляд, тісно пов'язані з характером патології та обсягом операції.

Причинами смертей були: ятрогенне ушкодження ПКА - в 1 хворого; вихідна важкість стану - в 1 хворого; поліорганна недостатність - у 2 пацієнтів. Таким чином, пацієнти, які потребують поєднаної операції з приводу патології аорти та супутнього ураження вінцевих артерій, мають високий ризик втручання. Поєднання двох патологій (патології аорти та коронарної) призводить до важчого за перебігом і ускладненого за прогнозом патофізіологічного стану. Першочергова повна реваскуляризація міокарда дозволяє виконати повноцінний захист міокарда, зменшити ступінь його ушкодження, значно скоротити час його ішемії та досягти кращих результатів.

Висновки. У пацієнтів з аневризмами аорти і супутнім ураженням вінцевих судин першим етапом операції повинна бути повна реваскудяризація міокарда 3 подальшою корекцією патології аорти.

\section{Література}

1. Методика защиты миокарда при хирургическом лечении сочетанной и выраженной коронарной патологии / Урсуленко В. И., Купчинский А. В., Береговой Б. Б. и 
др. // Щорічник наукових праць Асоціації серцево-судинних хірургів України. - 2013. - С. 514-516.

2. Дземешкевич С. Л., Стивенсон Л. У. Болезни аортального клапана: функция, диагностика, лечение. - М. : Медицинская литература от издательства: ГЗОТАРМЕД, 2000. - $288 \mathrm{c}$.

3. Cardiac operations in patients 80 years old and over/ Akins C. W, Dagget C. W., Vlahakes G. J. et al. //Ann Thorac Surg. - 2017. - № 64. - P. 606.
4. Repair of ischemic mitral regurgitation doesn't increase mortality or improve long-term survival in patients undergoing coronary revascularization: a propensity analysis / Diadoto M. D., Моoп M. K. et al. // Ann Thorac. Surg. - 2014. - Vol. 78. - P. 794-99.

5. Di Sesa V. J. Valvularand ischemic heart disease / In: Cardiac surgery in adult. Ed. H. L. - Edmunds. - New York : McGrow Hill. - 2013. - chap. 37.

\title{
Surgical treatment of aortic aneurysms combined with coronary artery disease
}

\section{Zhekov I. I., Kravchenko V. I., Kravchenko I. M., Zinchenko H. A., Perepeluyk A. I., Vayda V. V.}

National M. M. Amosov Institute of Cardiovascular Surgery National Academy of Medical Sciences of Ukraine (Kyiv)

In recent years, the proportion of operations with combined pathology of aortic aneurysms and coronary artery disease has increased. The combined operative intervention of the aortic aneurysm with concomitant coronary artery disease over the past decades has become widespread. The outcome of such interventions in modern cardiac surgical centers is $15-30 \%$. Reducing the duration of artificial blood flow and ischemic time for a myocardium is a major problem in order to reduce the operational risk and the likelihood of death in such operations.

Purpose: to evaluate the effectiveness of surgical correction of aortic aneurysms in combination with the restoration of myocardial revascularization.

Materials and methods. Starting from $01 / 01 / 2010$ to $31 / 12 / 2017,105$ patients were treated for the correction of aortic aneurysm and associated coronary artery disease.

Conclusions. In order to improve the immediate results of surgery in patients with aortic aneurysms and the associated coronary artery disease in the presence of suboclusions of the major coronary arteries, the first stage of the operation should be complete revascularization of the myocardium, followed by correction of aortic pathology.

Key words: aneurysm of the aorta, coronary arteries, coronary artery bypass grafting.

\section{Хирургическое лечение аневризм аорты в сочетании с поражением коронарных артерий сердца}

\author{
Жеков И. И., Кравченко В. И., Кравченко И. М., Зинченко Г.А., Перепелюк А. И., Вайда В. В. \\ ГУ «Национальный институт сердечно-сосудистой хирургии имени Н. М. Амосова НАМН» (Киев)
}

За последние годы увеличилась доля проведения операций с сочетанной патологией аневризм аорты и сопутствующим поражением коронарных артерий. Комбинированные оперативные вмешательства по поводу аневризм аорты с сопутствующим поражением коронарных артерий за последние десятилетия получили широкое распространение. Судьба таких вмешательств в современных кардиохирургических центрах составляет $15-30 \%$. Для уменьшения операционного риска и вероятности летального результата при выполнении подобных операций необходимо сокращение продолжительности искусственного кровообращения и ишемического времени для миокарда, что и составляет основную проблему.

Цель работы - оценить эффективность хирургической коррекции аневризм аорты в сочетании с восстановлением реваскуляризации миокарда.

Материалы и методы. С 01.01.2010 по 31.12.2017 было прооперировано 105 пациентов по поводу коррекции аневризм аорты и сопутствующего поражения коронарных артерий.

Выводы. Для улучшения непосредственных результатов операции у пациентов с аневризмами аорты и сопутствующим поражением коронарных сосудов при наличии субокклюзий основных ветвей венечных артерий первым этапом операции должна выполняться полная реваскуляризация миокарда с последующей коррекцией патологии аорты.

Ключевые слова: аневризма аорты, венечные артерии, коронарное шунтирование. 